\title{
THE STUDY OF INFLUENCE OF DUMPS ON ECOSYSTEM AND POPULATION HEALTH ON THE EXAMPLE OF SHW-5, CITY KYIV
}

\author{
Inesa Mihno \\ Department of Economic Cybernetics \\ National University of Bioresources and Management of Nature of Ukraine \\ 15 Heroiv oborony str., Kyiv, Ukraine, 03041 \\ Inessa_love@i.ua
}

\begin{abstract}
In this work were analyzed the causes of modern state of accumulation of the dangerous household wastes throughout the world and in Ukraine that is the global problem of mankind for today. It concerns especially the developing countries with essentially lower level of life and where the old technologies are used. The state and influence on environment on the example of SHW-5, situated near the city Kyiv were studied. The questionnaire was carried out among the local population at the different distances from the dump, including the influence on health, soils, water resources, air and other. It was revealed, that dumps negatively influence the ecosystem at more distance than it is fixed in regulatory acts. The speeds of accumulation of solid wastes at SHW-5 were assessed. The modern technologies, based on the use of mapping and satellite data, for receiving information as to the influence of dumps on the surrounding settlements and local population health were studied. The conclusions about the decrease of prices of land near the dump and irrational use of land resources were done. As a result of calculations the area of influence of dump and radius of distribution of the negative effects on population and ecosystem in whole were received. The modern technologies as to utilization of wastes in the world were studied and the wanted scenario of solving the problem by sorting wastes and their further processing for the secondary use was chosen. The recommendations as to decrease of influence of dumps on ecosystem by building of garbage-recycling plants using recycling system were given.
\end{abstract}

Keywords: dump, GI-systems, dumps influence, population health, price of land.

\section{Introduction}

Last decades the problem of accumulation and utilization of garbage became global for the whole mankind. The increase of population, economic growth, change of garbage structure lead to catastrophic state and needs immediate solving.

The problems of utilization of solid household wastes are urgent for many countries. The garbage outcome is $250-700 \mathrm{~kg}$ for one person per year, increasing by $4-6 \%$ for year, leaving behind the population increase [1].

\section{Analysis of literary data and statement of problem}

More than $80 \%$ of dumps of the solid household wastes (SHW) used in Ukraine for today, do not correspond to the sanitary norms, and are transformed into spontaneous dumps. The amount of wastes for one person in our country increases annually and for the present moment is 400 tons. The total mass of wastes, concentrated in surface depositories exceeded 25 billions of tons, among them toxic ones -5 billions of tons [3].

The most spread way of SHW treatment for today is their burial on the specially allotted polygons and dumps, especially for the countries with transitional economic formations (such as Ukraine) and developing countries. But for the developed ones, especially for members of European Union such form of SHW treatment is unacceptable at the modern stage in all aspects - from environmental point of view (in first turn) and from the point of view of SHW resource potential [4].

The modern technologies can solve this problem, because the garbage can be used secondary and in such a way can solve the problem of the raw material deficit [5].

Tardy removal of SHW worsens the sanitary state of settlements, can be the cause of diseases and epidemics, causes pollution of soils, underground and surface waters, atmospheric air. At the same time SHW is the source of secondary resources, which use allows provide the process the rational management of the nature [6]. 
In the developed countries the garbage sorting and recycling are used.

In the world practice introduction and realization of recycling programs by the state are actively carried out during the last 20-25 years. Despite the sufficient number of scientific works and projects in this sphere Ukraine has not the unitary complex mechanism of solution of problem of the wastes processing at the state level. The effectiveness of existing recycling programs is relatively low, so it is necessary to continue the studies of this question to reveal and define many priority directions. It is also worth underlining that such elaborations are insufficiently active in Ukraine [7].

The communal sphere in Ukraine is artificially monopolized. The tariffs of these services are set by the local authorities, based on the established state norms and regulations. It was established, that tariffs do not cover the costs of communal services in full for today and are essentially differentiated by regions. It results in impossibility to introduce the new technologies without involvement the outside investments [8].

\section{Aim and tasks of research}

The aim of the work is analysis of dumps influence on ecosystem in whole and people health for giving recommendations as to the further development in the sphere of garbage utilization in Ukraine.

For attaining this aim the next tasks were set:

1. Analysis of the modern state of dumps in Ukraine and the sphere of garbage utilization.

2. Variants of solving problem in the world countries.

3. The study of state of existent garbage polygons on the example of SHW-5 in city Kyiv.

4. Questionnaire of the local dwellers of the surrounding settlements as to complaints and SHW influence.

5. The study of the modern methods of polygons influence on the base of GI systems.

\section{Materials and methods of research}

In the work are used the methods of observations, comparison, synthesis, generalization, induction, deduction, questionnaire, mathematical methods of research.

For the end of 2014 in Ukraine were collected near 12,1 billions of tons of wastes [2].

Most of the modern SHW polygons don't correspond to the ecological norms and are not eco-friendly. Toxic filtrate pollutes soil and surface and ground waters, garbage rotting results in air pollution.

\section{Results of research}

City Kyiv is the one of largest producers of garbage. The main way of utilization it is a polygon burial. But within the city functions the combustion plant "Energy" that process garbage into energy, but it has the small capacities and old technologies that are not eco-friendly.

Most garbage comes to SHW-5 that is already overload and dangerous.

SHW-5 is situated in Obukhiv district of Kyiv region at the distance $22 \mathrm{~km}$ from city Kyiv. Its area, according to the official data, is 63,7 hectares, according to unofficial ones -65 hectares. The height of garbage mountains from the null mark (trench bottom) was $120 \mathrm{~m}$ in 2016, whereas in 2014 it was $102 \mathrm{~m}$. One ton of garbage is near 5 cubic meters of wastes. Since 1986 (year of creation) more than 6,5 millions of tons of wastes were collected on polygon. And the speed of accumulation increases each year.

The number of leaving trucks in workday was analyzed and conclusions were made on this base. Near 140 garbage trucks comes every day. The mean volume of garbage basket is $20 \mathrm{cu}-$ bic meters. So the approximate speed of accumulation of garbage for a day is 2800 cubic meters $=560$ tons. It is 201,6 thousands of tons per year. SHW state is characterized as catastrophic one and needs urgent actions. Garbage mountains are visible at the distance, and smell spreads over the large territories.

Almost all coming trucks are old and muddy. Green plantations are near the road to separate SHW, but garbage mountains are visible through the leaves. Stink is always present near the entrance to SHW. Small autos throw out garbage near the entrance, and homeless people take it and marginally sort it. Many dogs and birds strike eyes here. Passing around the polygon, we have 
seen auto-park and a little farm, where cow and sheep are kept. All animals live almost on SHW territory and are grown for the workers. The guard is always present at SHW, there are also video-cameras. On the other side of entrance the new basin for the burial of garbage was created. For that the forest was felled, because the natural landscape had many trees. The great number of birds and insects was observed. It is hard to breath because of bad smell.

I interrogated local dwellers in villages near the dump. 10 persons were interrogated in each settlement.

The results of research are presented on the Table 1.

\section{Table 1}

SHW-5 influence on population and ecosystem of surrounding settlements

\begin{tabular}{|c|c|c|c|c|c|}
\hline $\begin{array}{c}\text { Name of } \\
\text { settlement }\end{array}$ & $\begin{array}{l}\text { Distance to } \\
\text { the dump, cm }\end{array}$ & $\begin{array}{l}\text { Complaints } \\
\text { about air state }\end{array}$ & $\begin{array}{c}\text { Complaints } \\
\text { about water state }\end{array}$ & Complaints about health state & Other complaints \\
\hline Pidhyrtsy & 1,4 & Permanent stink & Unsuitable for use & $\begin{array}{c}8 \text { of } 10 \text { interrogated persons have } \\
\text { problems with cardiovascular } \\
\text { system, frequent ARD. } 3 \text { persons } \\
\text { have asthma, } 2 \text { interrogated } \\
\text { complaints against the permanent } \\
\text { head aches }\end{array}$ & $\begin{array}{c}\text { Large number of } \\
\text { birds, insects, homes } \\
\text { less people, decrease } \\
\text { of price of land }\end{array}$ \\
\hline Krenychy & 1 & Permanent stink & Unsuitable for use & $\begin{array}{l}\text { All interrogated talk about bad } \\
\text { health state and frequent ARD, } \\
\text { high percentage of children } \\
\text { with innate anomalies and dis- } \\
\text { eases, is observed in village }\end{array}$ & $\begin{array}{l}\text { Large number of } \\
\text { birds, insects, homes } \\
\text { less people, decrease } \\
\text { of price of land }\end{array}$ \\
\hline Romankiv & 3 & Permanent stink & Unsuitable for use & $\begin{array}{l}\text { ARD, decrease of immunity, } \\
\text { asthma in } 3 \text { of } 10\end{array}$ & $\begin{array}{l}\text { Large number of } \\
\text { birds, insects, homes } \\
\text { less people, decrease } \\
\text { of price of land }\end{array}$ \\
\hline Khodosiivka & 4,5 & Permanent stink & Unsuitable for use & $\begin{array}{l}\text { ARD, decrease of immunity, } \\
\text { cardio-vascular diseases }\end{array}$ & $\begin{array}{l}\text { Large number of } \\
\text { insects }\end{array}$ \\
\hline $\begin{array}{l}\text { Maly and Veliky } \\
\text { Dmytrovichy }\end{array}$ & 3,3 & Permanent stink & Unsuitable for use & $\begin{array}{c}\text { Decrease of immunity, cancer } \\
\text { diseases }\end{array}$ & \\
\hline Gvozdov & 3,5 & Permanent stink & Unsuitable for use & ARD, decrease of immunity & $\begin{array}{l}\text { Large number of } \\
\text { birds, problems } \\
\text { with agricultural } \\
\text { production }\end{array}$ \\
\hline Roslavichy & 6 & Season stink & $\begin{array}{l}\text { For household } \\
\text { needs only }\end{array}$ & $\mathrm{ARD}$, decrease of immunity & $\begin{array}{l}\text { Diseases of plants, } \\
\text { pests }\end{array}$ \\
\hline Lisnyky & 7,7 & Permanent stink & Unsuitable for use & $\begin{array}{l}\text { ARD, decrease of immuni- } \\
\text { ty, cardio-vascular diseases, } \\
\text { asthma }\end{array}$ & \\
\hline $\begin{array}{l}\text { Kruglyk, } \\
\text { Kremenische, } \\
\text { Novi } \\
\text { Bezradychy }\end{array}$ & $\begin{array}{c}9 \\
7,3\end{array}$ & Season stink & $\begin{array}{l}\text { For household } \\
\text { needs only }\end{array}$ & $\mathrm{ARD}$, decrease of immunity & $\begin{array}{l}\text { Diseases of agricul- } \\
\text { tural plants, crowds } \\
\text { of birds }\end{array}$ \\
\hline Zeleny Bir & 11 & Season stink & $\begin{array}{l}\text { For household } \\
\text { needs only }\end{array}$ & decrease of immunity & $\begin{array}{c}\text { Worsening of water } \\
\text { state in wells and } \\
\text { ponds }\end{array}$ \\
\hline
\end{tabular}


Table 1 allows make a conclusion about the negative influence of SWH-5 on ecosystem and braking of authorities in the process of solution of this problem.

The price of land decreases because of its closeness to the polygon and its pollution increases. The buildings in aforesaid villages are sold not so well like in other villages at the equal distance from the city Kyiv.

Vapors and gases from the dump are toxic ones and cause diseases, decrease immunity. Toxic substances accumulate on plants leaves, poisoning them, on buildings that create permanent danger and influence. Filtrate that penetrates in soil and underground waters poisons water and the products of life activity. Birds that feed on dump drink water in poisoned lakes. They also fly at the different distances and spread diseases and infections. Large number of homeless people works on dump and plunders homes.

Influence is also distributed on agricultural products by filtrate penetration, reproduction of pests and worsening of state of the whole ecosystem.

The negative factor of dumps is alienation of productive land and as the result decrease of the natural potential of country in whole.

Pollution of agricultural land condition not only the environmental problems, caused by penetration of chemical elements in soil waters, food products, planted on earth and so on but also economy and social factors of life. As a result of analysis it was revealed, that the main source of pollution of agricultural soils is filtrate discharges of polygon that are accumulated in soils and get into soil as a result of significant atmospheric precipitations that cause filtrate excess. The source of filtrate pollution is mainly disintegration of food wastes and oxidation of metals, because the process of decay of organic compounds is extremely slow. Filtrate is created on the plot of burial during the warm and cold seasons. In warm period - there are precipitations as rain. Creation of filtrate in cold season is connected with the snow thawing on surface of wastes at the expense of heat that is released at disintegration of the organic raw material in depth of the dump body and also with the burial of significant part of snow together with composing wastes. On dumps, built without accordance with rules of environment protection, filtrate freely flows on relief, penetrates in soil, soil and underground waters. Penetration of filtrate in soils and soil waters can lead to the significant pollution of agricultural lands not only with organic and inorganic compounds but also with helminth eggs, pathogenic microorganisms [9].

The development of technologies and internet led to the new ways of study of ecosystem. One of them is creation of GI systems and use of interactive maps. Such system allows observe all changes in ecological state of soils fast and effectively according to the given information.

GI it is a modern computer technology that allows combine the model image of territory (electronic reflection of maps, schemes, cosmo, aero-reflections of the ear surface) with information of table type (diverse statistic data, lists and so on). This information can be social, political, environmental or demographic one that is any information) that can be represented on the map. The special means allow carry out analytic processing of the data and in more complicate cases modeling of the real events.

Using the method of processing of cosmic images on the base of comparison of spectral characteristics of studied objects the location of unlawful dumps can be identified, the limits of dump spread can be specified [10].

For today GI is a most effective instrument of cognition and description of geographic environment that permanently changes. These systems are used for solution of many practical tasks, connected in one or another way with spatial-distributed data, used for providing environmental safety and stable development of regions. Geographic informational systems can be used in such fields as: analysis of the data of environmental monitoring; creation of digital maps that demonstrate the state of environment; analysis of changes that took place in the studied region; prognostication of consequences of making one or another economic decisions [11].

Calculations were carried out on the base of Googleearth and Googleearthpro program, which screen is presented on the Fig. 1. 


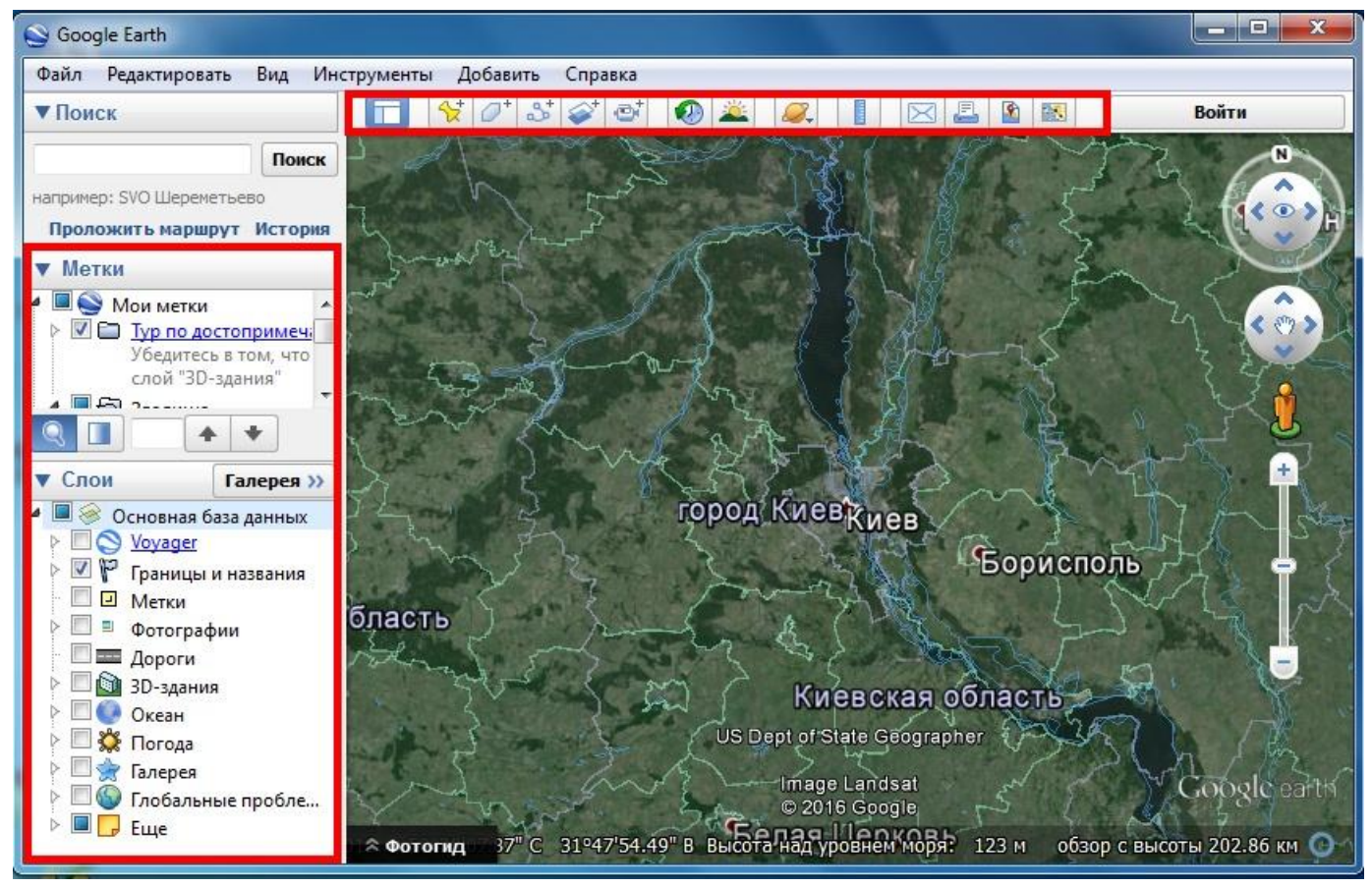

Fig. 1 Google Earth instruments board

Instrument "Marks" is used for separation and saving of data about the place, selected on the map by user. In Google Earth are several types of marks, the point marks as marker that has only one point with coordinates and polygons that have certain number of points with coordinates on area.

The studied villages were pointed on the map for calculation of area of dump influence on surrounding territories.

Using installed instruments the influence area was measured, it was 170 square $\mathrm{km}$.

For the study of dump influence radius was used the formula:

$$
\mathrm{S}=\pi \mathrm{R}^{2}
$$

It was calculated, that the influence radius is $7,4 \mathrm{~km}$. But according to the sanitary-epidemiologic regulations the territory of SHW polygons location must be in no less than $1 \mathrm{~km}$ from the city limits. Sanitary-defending zone must be $0,5 \mathrm{~km}$ to the housing system. The research showed us that the polygon influence is much more, that is proved by interrogation of local population.

The building of the modern garbage-processing complexes that use new technologies and allows the secondary use of garbage is offered. The great negative influence of polygon burial and garbage-burning, used in Ukraine, cause the pollution of ecosystem in whole. It is necessary to analyze the experience of developed countries and invest the sphere of wastes processing for introduction of market of secondary resources and improvement of the social well-being of population.

For today the number of illegal dumps in Ukraine grows, these dumps are not controlled and don't have even the primitive means for decrease of influence on ecosystem that makes the problem of garbage accumulation more urgent.

\section{Discussion of the results of research}

As a result of received data it was revealed, that the use of land for polygons is irrational, because it can be productive and used for planting agricultural production. It can inspire the local authorities to actions, directed on involvement of investments and building of the modern garbage-processing plant, because SHW-5 influence is more that it is defined by the sanitary-hygienic norms. This territory must be excluded from the use because of danger for the population health. 
It was also revealed, that SHW-5 influence of the air at the distance more than $6 \mathrm{~km}$ depends on season and speed and direction of wind that allows correctly assess the danger at purchase of land or building in this region. But for more objective image it is necessary to interrogate each dweller from these settlements.

Earlier it was carried out the analysis of this problem in the world, problem of taxing and payment of housing tariffs, it was also build the model of introduction of the garbage-processing complex in Ukraine. It is also planned to make the official appeal to the regional council of Kyiv region with offer as to the problem of garbage utilization.

\section{Conclusions}

1. Situation with treatment of garbage in Ukraine is catastrophic and needs immediate solving.

2. In developed countries the innovative technologies are used, which base is sorting and recycling for garbage utilization. Countries that are developing (including Ukraine) mainly use the polygon burial that is dangerous and irrational. In best case the combustion plants are built that is also the old technology that influences ecosystem and pollutes it.

3. SHW-5 state is unsatisfactory. There was offered the building of the modern garbage-processing complex and refusal from the polygon burial.

4. According to the questionnaire data, SHW-5 influence spreads on the large territories and leads to the worsening of the state of whole ecosystem and population health.

5. Using the modern GI systems the monitoring of the use of land resources, analysis and measurement them in time are possible.

\section{References}

[1] Berezovchuk Yu. S., Orexivskyj Ye. F. (2016). Alternatyvni dzherela energiyi. Krok u nauku, 2, 94-103

[2] Statystychnyj shhorichnyk Ukrayiny za 2014 (2015). Kyiv: Derzhavna sluzhba statystyky Ukrayiny. Available at: http://ukrstat.gov.ua

[3] Kachynskyj, A. B. (2001). Ekologichna bezpeka ukrayiny:systemnyj analiz perspektyv pokrashhennya. 252. Available at: http://petrukrv.vk.vntu.edu.ua/file/beef10370d5c14be089ba59479b47df2.doc

[4] Ishhenko, V. A., Turchyk, P. M. (2012). Analiz shlyahiv vykorystannya svitovogo dosvidu povodzhennya iz tverdymy pobutovymy vidxodamy v Ukrayini. Visnyk Vinnyczkogo politexnichnogo instytutu, 2, 25-30.

[5] Dzyad, O. V., Czvyetayeva, K. V. (2016). Resajkling municypalnyh vidhodiv u promyslovo rozvynenyh krayinah svitu: porivnyalnyj aspekt. Visnyk Dnipropetrovskogo universytetu "Svitove gospodarstvo i mizhnarodni ekonomichni vidnosyny", 7 (23), 3-12.

[6] Bozhydarnik, V. V., Kartava, O. F., Kartavyj, A. G. (2009). Shlyahy optymizaciyi vplyvu miskogo zvalyshha smittya na ekologichnyj stan prymiskyh terytorij. Naukovi praci Chornomorskogo derzhavnogo universytetu imeni Petra Mogyly "Tehnogenna bezpeka”, 111 (98), 158-161.

[7] Popova, Yu. M., Patutina, V. Yu. (2010). Osoblyvosti vprovadzhennya zarubizhnrgo dosvidu pid chas rozroblennya derzhavnyx recyklingovyx program v Ukrayini. Visnyk Nacionalnogo universytetu «Lvivska politexnika», 690, 689-694.

[8] Volohova, I. S. (2016). Taryfne regulyuvannya ta konceptualizaciya rozvytku sfery zhytlovo-komunalnogo gospodarstva. Problemy ta perspektyvy rozvytku pidpryyemnycztva: Zbirnyk naukovyh pracz Kharkivskogo nacionalnogo avtomobilno-dorozhnogo universytetu, 1 (12), 17-23.

[9] Yeremyeyev, I. S., Marchuk, S. V. (2015). Doslidzhennya vplyvu poligoniv tpv na zemli silskogospodarskogo pryznachennya. Agrosvit, 15, 3-8.

[10] Domanska, M. V., Bodnar, S. P. (2013). Identyfikaciya nesankcionovanyh zvalyshh pobutovyh vidhodiv za materialamy DZZ. Chasopys kartografiyi, 7, 114-126.

[11] Myhajlova, Ye. O., Protasenko, O. F. (2016). Vykorystannya geoinformacijnyh system dlya zabezpechennya ekologichnoyi bezpeky. Problemy ta perspektyvy rozvytku IT-industriyi. Kharkiv: KhNEU im. S. Kuznecya, 70. 